\title{
PHYTOPLANKTON COMPOSITION OF MARICULTURE AREA IN SUNGAI UDANG, PENANG, MALAYSIA, THE NORTHERN STRAIT OF MALACCA
}

\author{
Roziawati Mohd Razali ${ }^{1 a^{*}}$, Masazurah A. Rahim ${ }^{2 a}$ and Ku Kassim Ku Yaacob ${ }^{3 a}$
}

${ }^{a}$ Fisheries Research Institute Batu Maung, Department of Fisheries Malaysia, 11960 Batu Maung, Penang, MALAYSIA. Email: roziawati@dof.gov.my ${ }^{1}$; masazurah@gmail.com²; kukassim@gmail.com ${ }^{3}$

*Corresponding author: roziawati@dof.gov.my

Received: $10^{\text {th }}$ Nov $2020 \quad$ Accepted: $22^{\text {nd }}$ Mar 2021

Published: $30^{\text {th }}$ Jun 2021

DOI: https://doi.org/10.22452/mjs.vol40no2.7

\begin{abstract}
A study was conducted in the marine finfish cage culture area in Sungai Udang, Penang, at the northern part of the Malacca Straits to examine the phytoplankton composition and abundance especially for potentially harmful phytoplankton. Monthly sampling were taken from March 2016 to January 2017 at nine sampling stations. Physiochemical parameters of surface seawater such as $\mathrm{pH}$, dissolved oxygen, temperature, salinity, total suspended solids, and nutrients (nitrate, nitrite, ammonium, phosphate and silicate) were also measured. A total of 54 phytoplankton taxa were recorded, with 37 genera belonged to diatoms, 15 of dinoflagellates, and 2 of cyanobacteria. The composition of phytoplankton was dominated by diatoms $(>85 \%)$ at all sampling stations throughout the sampling period. The phytoplankton abundance ranged between $2.6 \times 10^{3}$ cells $\mathrm{L}^{-1}$ and $5.8 \times 10^{6}$ cells $\mathrm{L}^{-1}$. The potentially harmful toxic phytoplankton observed throughout the sampling period are dinoflagellates Alexandrium spp., Prorocentrum micans and Dinophysis caudata and diatoms, Pseudo-nitzchia spp but in low cell density. A total of six bloom-forming phytoplankton that can potentially trigger mass mortality of cultured fish such as Akashiwo sanguinea, Chaetoceros spp., Ceratium furca, Ceratium fusus, Margalefidinium spp. and Karlodinium spp. recorded at this area were relatively low in cell densities. Furthermore, no fish kill incident was reported in the area from blooms of phytoplankton during the period of study. Even though potentially harmful phytoplankton present were in low densities, they may pose significant risks to aquaculture activity if there is a sudden bloom. Hence, a monitoring program should be implemented to provide early warning of harmful algae blooms and safeguard the aquaculture industry in Sungai Udang, Penang.
\end{abstract}

Keywords: mariculture area, algae bloom, water quality parameters, Strait of Malacca

\section{INTRODUCTION}

Sungai Udang located in Seberang Perai Selatan, Penang is an important marine finfish cage culture area in Malaysia. Penang is a major contributor to the production of Malaysia's cage cultured marine finfish. In 2017, Penang produced $23,380.32$ tonnes of marine finfish valued at RM510.12 million, a $63.39 \%$ of the total cage-cultured marine finfish production in Malaysia (Annual Fisheries Statistics, 2017). A total of 211 out of 285 marine culturists in Penang are from Sungai Udang (unpublished data, DoF). The main species of marine fish cultured are sea bass (Lates calcarifer), groupers (Epinephelus spp.), golden pomfrets (Trachinotus blochii), 
golden trevally (Caranx spp.), and red snapper (Lutjanus argentimaculatus).

Phytoplankton is a primary producer in aquatic ecosystems. However, certain types of phytoplankton may become harmful if their presence is in unnaturally high abundance. Harmful phytoplankton could be divided into two main types, first is the toxin producer such as Alexandrium spp., Dinophysis spp., and Pseudo-nitzchia spp. resulting in shellfish poisoning in human; and second, bloom-forming group such as Ceratium spp. and Noctiluca scintillans which can cause low oxygen or anoxia/hypoxia and mortality of aquatic life (Hallegraeff, 2003; Omura et al., 2012). The occurrence of harmful phytoplankton species in the cage culturing area may pose potential threats to the fisheries industries.

Phytoplankton growth is regulated by environmental parameters such as sunlight, salinity, temperature and nutrients (Anderson et al., 2002). In favourable conditions such as eutrophication, some phytoplankton can rapidly increase in density. Eutrophication refers to high enrichment of nutrients particularly phosphorus, nitrite, nitrate, and silicate in the aquatic ecosystem that may trigger algal blooms (Anderson et al., 2002; Heisler et al., 2008; Wurtsbaugh et al., 2019). Phytoplankton abundance and species composition can be a good indicator of water quality because it actively responds rapidly and sensitively to environmental changes such as nutrient enrichment (Sadally et al., 2014; Willen, 2007). Phytoplankton composition and abundance are also used as the early-warning signals that describe the health condition of an aquatic ecosystem (Wan Maznah, 2010). Ironically, some issues of nutrient or organic enrichment caused by the aquaculture activities that are not in accordance with the standards set will eventually affect cultured fish. Increased nutrient concentration in fish farm areas may cause an increase of phytoplankton biomass and also harmful algal blooms that subsequently could affect cultured fish (Anderson, 2012; Yin et al., 2008).

Blooms of harmful phytoplankton have a significant impact on fisheries industries by triggering massive fish deaths, especially caged fish due to oxygen depletion or excretion of toxic bioactive compounds that may clog, irritate or damage the fish gills and lead to suffocation (Rensel \& Whyte, 2003). In Malaysia, several harmful phytoplankton species were reportedly have caused mass mortality of cultured fish such as Chattonella sp. (Choo, 1994), Margalefidinium polykrikoides (Anton et al., 2008; NorRohaida et al., 2015), Karlodinium australe (Lim et al., 2014) and Noctiluca scintillans (Choo, 1994; Roziawati et al., 2016). Margalefidinium polykrikoides have been associated with massive fish kill events in Sabah and Perak coastal waters (Anton et al., 2008; NorRohaida et al., 2015). In February 2014 a bloom of Karlodinium australe threatened caged fish in West Johor Straits (Lim et al., 2014) and recurred in February 2015 (Teng et al., 2016). Harmful algae blooms incident associated with massive deaths of caged fish in Kuala Gula, Perak in 2016 was attributed to Noctiluca scintillans species which caused more than RM500,000 losses to mariculturists (Roziawati et al., 2016).

Nevertheless, not all cases of mass fish mortalities caused by phytoplankton bloom in cages have been identified. In 2005, a fish kill event with more than RM20 million losses to mariculturists have been reported in Penang but the causative organism remained obscure (Lim et al., 2012). In January 2016, mass mortality of caged fish in Sungai Udang, Penang was reported, and again, the cause of death remains unclear (Roziawati \& Shahunthala, 2017). In between those two events, monitoring activities done in nearby cage culture areas in Pulau Aman, Penang detected the presence of several potentially harmful phytoplankton species (Roziawati 
et al., 2015). In Peninsular Malaysia, regular HABs monitoring programs are currently implemented only in important mollusk culture areas under the National Shellfish Sanitation Program (NSSP) by the Department of Fisheries focusing on the toxic phytoplankton species and toxins in shellfish. There are very limited baseline data on potentially harmful phytoplankton species in the fish cage culture area. More locations should be included in the country's HABs monitoring program especially areas with previously known HABs hot spots where aquaculture activities have been established. Thus, the aims of this study are to document the species composition and abundance of phytoplankton in the finfish cage culture area in Sungai Udang, Penang that could contribute information on the distribution of potentially harmful phytoplankton in the region and as an inventory of Malaysia's species for monitoring purposes.

\section{MATERIALS AND METHODS}

\subsection{Sampling}

The phytoplankton sampling was done on monthly basis from March 2016 to January 2017 at nine stations of Sungai Udang, Penang area (Figure 1, Table 1). Station 1 (05 $\left.^{\circ} 12^{\prime} 29.7^{\prime \prime N}, 100^{\circ} 24^{\prime} 55.5^{\prime \prime} \mathrm{E}\right)$ was situated near the Sungai Tengah river mouth, Station $2\left(05^{\circ} 12^{\prime} 06.4^{\prime \prime N}\right.$, $\left.100^{\circ} 23^{\prime} 58.1^{\prime \prime E}\right)$, Station $3\left(05^{\circ} 12^{\prime} 32.2^{\prime \prime} \mathrm{N}\right.$, $\left.100^{\circ} 23^{\prime} 49.2^{\prime \prime E}\right)$, Station 4 (05 $13^{\prime} 10.0^{\prime \prime} \mathrm{N}$, $\left.100^{\circ} 23^{\prime} 55.7^{\prime \prime} \mathrm{E}\right)$, Station $5\left(05^{\circ} 13^{\prime} 18.8^{\prime \prime} \mathrm{N}\right.$, $\left.100^{\circ} 23^{\prime} 26.9^{\prime \prime E}\right)$, Station 6 (05 $133^{\prime} 24.1^{\prime \prime N}$, $\left.100^{\circ} 22^{\prime} 50.0^{\prime \prime} \mathrm{E}\right)$ and Station 7 $\left(05^{\circ} 12^{\prime} 55.9^{\prime \prime} \mathrm{N}, \quad 100^{\circ} 23^{\prime} 17.2^{\prime \prime} \mathrm{E}\right) \quad$ located around the fish cages. Station 8 $\left(05^{\circ} 14^{\prime} 0.97^{\prime \prime} \mathrm{N}, 100^{\circ} 21^{\prime} 36.9^{\prime \prime} \mathrm{E}\right)$ is outside the aquaculture area while Station 9 $\left(05^{\circ} 11^{\prime} 32.3^{\prime \prime} \mathrm{N}, 100^{\circ} 24^{\prime} 23.3^{\prime \prime} \mathrm{E}\right)$ is near the river mouth of Sungai Kerian. A total of one liter (1L) of surface water were sampled using Van Dorn's sampler. Samples were then concentrated through a $20 \mu \mathrm{m}$ net and preserved in acidic Lugol's solution.

Table 1. Sampling date and respective season during the study

\begin{tabular}{ccc}
\hline $\begin{array}{c}\text { Sampling } \\
\text { number }\end{array}$ & Date & Season \\
\hline 1. & 8 March 2016 & Northeast Monsoon \\
2. & 4 April 2016 & Inter-monsoon season 1 \\
3. & 4 May 2016 & Southwest Monsoon \\
4. & 2 June 2016 & Southwest Monsoon \\
5. & 12 July 2016 & Southwest Monsoon \\
6. & 1 August 2016 & Southwest Monsoon \\
7. & 5 September 2016 & Southwest Monsoon \\
8. & 4 October 2016 & Inter-monsoon season 2 \\
9. & 5 November 2016 & Northeast Monsoon \\
10. & 4 December 2016 & Northeast Monsoon \\
11. & 5 January 2017 & Northeast Monsoon \\
\hline
\end{tabular}




\subsection{Physico-Chemical Properties}

Surface seawater physico-chemical parameters such as $\mathrm{pH}$, temperature, salinity and dissolved oxygen (DO) were measured in situ using a Hydrolab Quanta multiparameter water quality probe (Loveland, CO, USA) in triplicate. Water samples for dissolved inorganic nutrients such as nitrate, nitrite, phosphate, ammonium, silicate and total suspended solid were brought back to the laboratory and immediately analysed spectrophotometrically by using a HACH DREL 2010 (HACH, USA). Chlorophyll-a (Chl-a) concentration was measured in situ using a Hydrolab MS5 chlorophyll probe (Loveland, Co, USA). One-way Analysis of Variance (ANOVA) was analysed using GraphPad Prism 6 to determine differences in water quality parameters among the sampling stations.

\subsection{Phytoplankton identification and enumeration}

Phytoplankton identification was carried out based on identification books, Tomas (1997), Backer et al., (2003), and Omura et al., (2012). The micrographs for each phytoplankton are taken using CCD camera and Analysis (R) software (Soft Imaging System Inc., USA). A concentrated phytoplankton sub-sample $(1 \mathrm{~mL})$ was placed in the counting chamber SedgewickRafter and enumerated under an inverted microscope Olympus IX70 (Olympus, Tokyo, Japan) at 100 times magnification. The cell density, cell $\mathrm{L}^{-1}$ for each phytoplankton taxon was calculated in three replications in each sample.

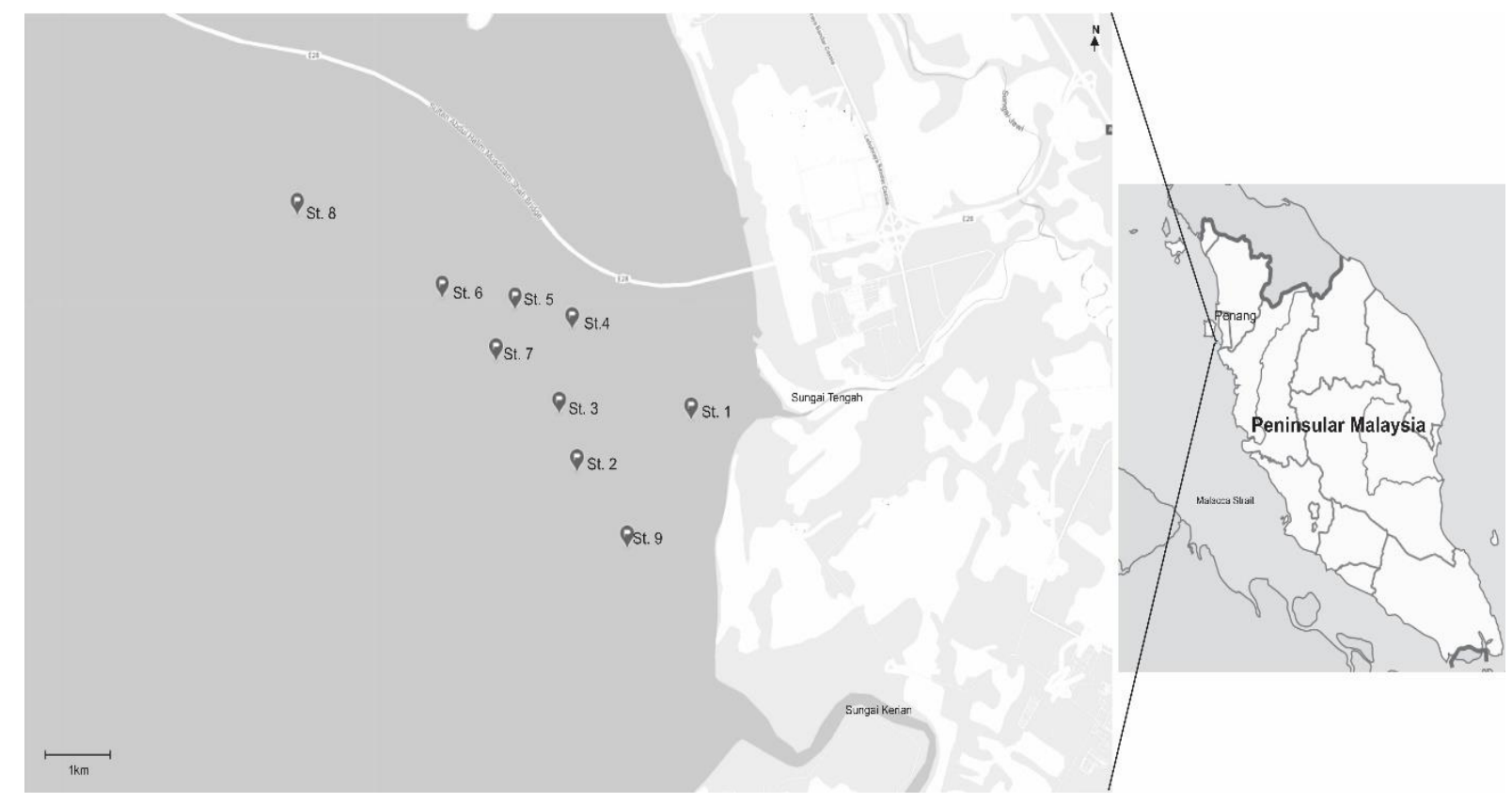

Figure 1. Map of Sungai Udang, Penang showing the sampling stations (St. 1, St. 2, St. 3, St. 4, St. 5, St. 6, St. 7, St. 8 and St. 9). 


\section{RESULTS \& DISCUSSIONS}

\subsection{Phytoplankton composition}

A total of 54 phytoplankton taxa were identified during the sampling activities. It consists of three main groups, i.e. diatoms (37 genera), dinoflagellates (15 genera) and cyanobacteria (2 genera). Phytoplankton documented in Sungai Udang, Penang are listed in Table 2. Cell density of phytoplankton and Chlorophyll-a (chl-a) concentrations in all sampling stations showed a similar trend where they fluctuated throughout the sampling period (Figure 2). The cell density of phytoplankton at all sampling stations ranged from $2.6 \times 10^{3}$ cells $\mathrm{L}^{-1}$ to $5.8 \times 10^{6}$ cells $\mathrm{L}^{-1}$. The highest abundance of phytoplankton appeared at St. 8 in early September 2016 with $45 \%$ of Lauderia sp. being the dominant species. While the lowest abundance event was recorded at St. 4 in December 2016. In comparison, cell density of phytoplankton in the nearby aquaculture area of Pulau Aman, Penang ranged from $1.44 \times 10^{4}$ cells $\mathrm{L}^{-1}$ to $4.01 \times 10^{6}$ cells L ${ }^{-1}$ (Roziawati et al., 2015) and Sepanggar Bay in Sabah, Malaysia ranged from $7.10 \times 10^{5}$ cells $\mathrm{L}^{-1}$ to $2.05 \times 10^{6}$ cells $\mathrm{L}^{-1}$ (Madihah et al., 2008). In this study, the concentration of chl-a ranged from $1.013 \mu \mathrm{g} \mathrm{L}^{-1}$ (October 2016) at St. 6 to $20.85 \mu \mathrm{g} \mathrm{L}^{-1}$ at St. 1 (June 2016).

The productivity of an aquatic system can usually be evaluated from the presence or abundance of phytoplankton. In the case of polluted waters, the phytoplankton composition in that particular water body will be very low (Pasztaleniec \& Poniewozik, 2010; Veronica et al., 2014). Waters with low fertility levels have the presence of phytoplankton less than $1.0 \times 10^{4}$ cells $\mathrm{L}^{-1}$, moderate fertility is more than $1.0 \times 10^{4}$ cells $\mathrm{L}^{-1}$, while very high fertility is more than $1.0 \times 10^{7}$ cells $\mathrm{L}^{-1}$. Phytoplankton abundance with of more than $1.0 \times 10^{7}$ cells L ${ }^{-1}$ is called blooms (Veronica et al., 2014). However, the bloom of harmful phytoplankton was not observed in all sampling stations during the period of study.

Diatoms were found as dominant at all sampling stations with more than $86.6 \%$ of the total phytoplankton throughout the sampling period except in July 2016 at St. $8(60.6 \%)$. Meanwhile, the percentage of dinoflagellates remained low during the study from $1 \%$ to $14 \%$ of total density except in July 2016 at St. 8 (35.6\%). A similar finding was reported in the previous studies where the diatoms was the most abundant phytoplankton in comparison with the other groups (Carter et al., 2005; Majbritt et al., 2004; Normawaty et al., 2013; Sidik et al., 2008). The composition of phytoplankton in the nearby finfish cage culture area of Pulau Aman, Penang was also dominated with more than $90 \%$ diatoms. Diatoms have a fast growth rate and can rapidly grow in high nutrient concentration (Carter et al., 2005; Polat, 2007; Schluter, 1998).

Phytoplankton composition in Sungai Udang was dominated by different species of diatoms in each sampling. Cyclotella spp. was dominant once in early March 2016 for all stations at more than $58 \%$ of total phytoplankton except station 8. Meanwhile, Skeletonema spp. was found dominant in April at over $30 \%$ of total phytoplankton at St. 1, St. 2, St. 3 and St. 4. Throughout June 2016 to August 2016, Helicotheca spp. dominated at all sampling stations at more than $30 \%$ to 
$94 \%$ of total phytoplankton. This dominant species was however replaced by Skeletonema spp. and Chaetoceros spp. in October and November 2016. Nonetheless, Eucamphia spp. was dominant in January 2017 at all sampling stations at over $30 \%$ of total phytoplankton. The marine fish cage culture area in Pulau Aman, Penang showed phytoplankton composition was also dominated by different species of diatoms, i.e. Skeletonema spp., Thallassiosira spp. and Chaetoceros spp. at each sampling occasion (Roziawati et al., 2015). Similarly, in the aquaculture area of Sepanggar Bay, Sabah the water is dominated by Coscinodiscus spp., Chaetoceros spp. and Bacteriastrum spp. (Madihah et al., 2008).

The potentially harmful toxic phytoplankton recorded throughout the study period are dinoflagellates Alexandrium spp., Prorocentrum micans and Dinophysis caudata and diatoms, Pseudo-nitzchia spp but in low cell density. Bloom-forming and non-toxic phytoplankton such as Akashiwo sanguinea, Ceratium furca, Ceratium fusus, Chaetoceros spp. and Skeletonema spp. were commonly found in each sampling but also low in density. Akashiwo sanguinea, Ceratium furca and Ceratium fusus were reported as commonly found in low density in coastal waters off Melaka (Normawaty et al., 2007), Sg. Jarum Mas, Perak (Roziawati \& Faazaz, 2011), Tebrau Strait (Lim et al., 2014) and Pulau Aman, Penang (Roziawati et al., 2015). Akashiwo sanguinea was reported as a fish killer (Cardwell, 1979) and caused fish mortality along Bolivar Peninsula, Texas in 2007 (Antonietta, 2016). Ceratium fusus has caused discoloration of the water and massive death of marine organisms in the Oman coastal water (Al Gheilani et al., 2011) whereas red discoloration of Penang and Perak coastal waters in 2007 and 2008 are caused by blooms of Ceratium furca (Deparment of Fisheries, 2007). In the present study, Ceratium furca was observed in almost every sampling, with the maximum cell density of $1.1 \times 10^{3}$ cells $\mathrm{L}^{-1}$. Margalefidinium spp., Karlodinium spp., Ceratium trichoceros and Ceratium tripos were rarely observed in low density throughout the sampling period. A bloom of Margalefidinium polykrikoides with a cell density $1.5 \times 10^{7}$ cells $\mathrm{L}^{-1}$ was reportedly responsible for the mortality of cultured fish in Sepanggar Bay, off Kota Kinabalu, Sabah in 2005 (Anton et al., 2008). Died fish occurrence in Tanjung Kupang, Johor cages in 2014 were attributed to the Karlodinium australe with a bloom concentration of $1.25 \times 10^{6}$ cells $\mathrm{L}^{-1}$ (Lim et al., 2014). Among other potentially harmful phytoplankton, Chaetoceros spp. was recorded with the highest maximum cell density, $3.90 \times 10^{5}$ cells $\mathrm{L}^{-1}$ in November 2016 at St. 4. Chaetoceros spp. had been reported to cause fish mortality in fish cages (Bell, 1961; Helleren, 2016; Rensel \& Whyte, 2003). Chaetoceros concavicornis, Chaetoceros convolutus, and Chaetoceros danicus have caused extensive fish kills in aquaculture industries in Washington state (Horner et al., 1997). The cell densities of Chaetoceros spp. reached up to $7.48 \times 10^{5}$ cells $\mathrm{L}^{-1}$ and has been linked to fish mortality events in Cockburn Sound, Western Australia, (Helleren, 2016). However, in the present study, no fish kill event due to phytoplankton was recorded throughout the sampling period. 

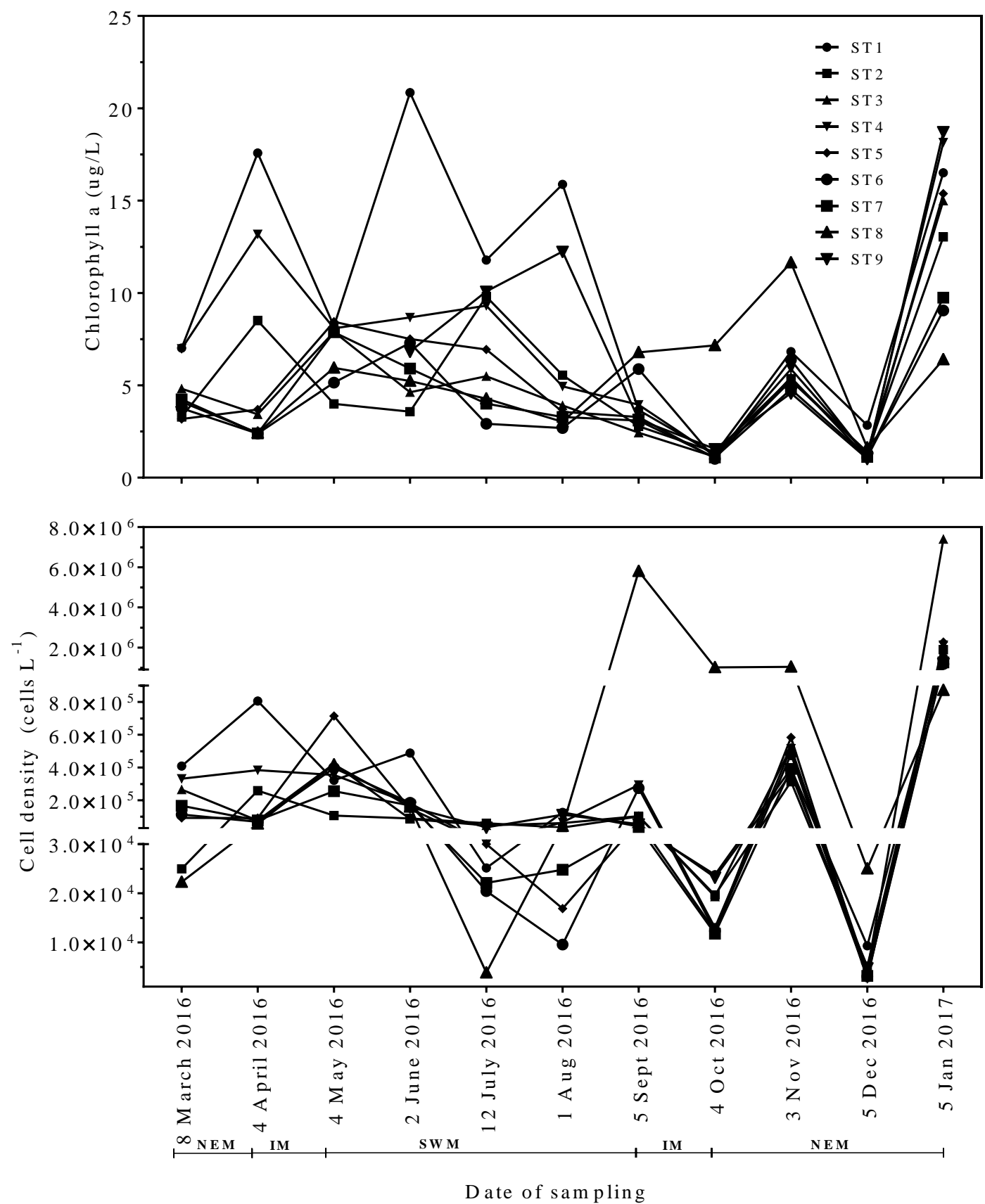

Figure 2. Cell density of phytoplankton in nine sampling stations of Sungai Udang, Penang from Mac 2016 to January 2017 
Table 2. Phytoplankton taxa of Sungai Udang, Penang identified in this study. An asterisk indicates potentially harmful taxon.

\begin{tabular}{|c|c|c|}
\hline $\begin{array}{c}\text { Diatoms } \\
\text { Pennate Diatoms }\end{array}$ & \multicolumn{2}{|c|}{ Centric Diatoms } \\
\hline Amphora spp. & Bacteriastrum spp. & Lithodesmium spp. \\
\hline Amphiprora spp. & Bellerochea spp. & Melosira spp. \\
\hline Asterionella spp. & Biddulphia spp. & Meuniera membranacea \\
\hline Bacillaria spp. & Chaetoceros spp.* & Odontella spp. \\
\hline Cylindrotheca closterium & Corethron spp. & Paralia spp. \\
\hline Climacosphenia spp. & Coscinodiscus spp. & Planktoniella sol \\
\hline Gyrosigma spp. & Cyclotella spp. & Rhizosolenia spp. \\
\hline Navicula spp. & Detonula spp. & Proboscia spp. \\
\hline Nitzschia longissima & Ditylum spp. & Skeletonema spp. * \\
\hline Nitzschia spp. & Eucampia spp & Thalassiosira spp. \\
\hline Pleurosigma spp. & Guinardia spp. & Triceratium spp. \\
\hline Pseudo-nitzschia spp.* & Hemiaulus spp. & \\
\hline Surirella spp. & Leptocylindrus spp. & \\
\hline Dinoflagellates & & Cyanobacteria \\
\hline Alexandrium spp.* & Gonyaulax spp. & $\overline{\text { Anabeana spp. }}$ \\
\hline Akashiwo sanguinea* & Gyrodinium spp. & Trichodesmium spp. \\
\hline Ceratium furca * & Gymnodinium spp. & \\
\hline Ceratium fusus* & Karlodinium sp. * & \\
\hline Ceratium trichoceros & Prorocentrum gracile* & \\
\hline Ceratium tripos & Prorocentrum micans* & \\
\hline Margalefidinium spp.* & Protoperidinium spp. & \\
\hline Dinophysis caudata* & Pyrophacus spp. & \\
\hline Dinophysis spp. & Polykrikos spp. & \\
\hline Fragilidinium spp. & Scripsiella spp. & \\
\hline
\end{tabular}

\subsection{Physico-chemical properties of seawater}

Penang faces two monsoon winds, the Northeast Monsoon (November to March) and the Southwest Monsoon (May to September) and receives more rainfall during the Southwest Monsoon (Ying \& Abdul Naser, 2019). The total monthly rainfall of Bayan Lepas Station, Penang from January 2016 to January 2017 obtained from Malaysian Metrological Services indicated that the sampling area experienced the dry season from January 2016 to April 2016, while the wet season was from September 2016 to November 2016 (Figure 3). The lowest rainfall was in February $(30.2 \mathrm{~mm})$ and the highest in October $(420.4 \mathrm{~mm})$. This was similarly reported by Yasser (2003) and Ying and Abdul Naser (2019) that stated low rainfall in Penang in February while heavy rainfall occurred in October.

The values of physicochemical parameters at different sampling stations in 
Sungai Udang are presented in Figure 4. One-way Analysis of Variance (ANOVA) showed a significant difference among stations for temperature $(\mathrm{p}=0.001), \mathrm{pH}$ $(\mathrm{p}=0.016)$, salinity $(\mathrm{p}<0.0001)$, dissolved oxygen $(\mathrm{p}=0.025)$ and total suspended solids $(\mathrm{p}=0.009)$, while turbidity $(\mathrm{p}=0.05)$ showed no significant difference. High temperature values were recorded at $32.39 \pm 0.09^{\circ} \mathrm{C}$ in May 2016 at St. 1 and low values of $29.00 \pm 0.01^{\circ} \mathrm{C}$ was recorded in September 2016 at St. 8. Temperature declined from June to September 2016 and slightly increased in October 2016. The low temperature could be attributed by the high rainfall received during the southwest monsoon season (June to September). The fluctuation of water $\mathrm{pH}$ was observed over the sampling period but it was consistently above neutral $(>7.0)$ in the range of $7.37 \pm 0.05$ to $8.57 \pm 0.06$. The highest $\mathrm{pH}$ was recorded at Station 1 in July 2016 and the lowest in September 2016 at Station 9. Salinity ranged from $23.64 \pm 2.23 \mathrm{ppt}$ to $30.52 \pm 0.82 \mathrm{ppt}$ with the highest values in April 2016 and the lowest in December 2016 at most studied stations. Seawater experienced dilution by precipitation and floodwater during rainy season where salinity was found to decline from October 2016 to January 2017. Dissolved oxygen (DO) generally exceeded $4.0 \mathrm{mg} \mathrm{L}^{-1}$ throughout the study period except in March at St. 2 and St. 3 and in December 2016 for most studied stations which ranged from $2.36 \pm 0.04 \mathrm{mg} \mathrm{L}^{-1}$ (St. 2, March) to $9.18 \pm 0.20 \mathrm{mg} \mathrm{L}^{-1}$ (St. 1, April). Total suspended solids (TSS) were below the MWQS of $50 \mathrm{mg} \mathrm{L}^{-1}$ except in June and September 2016 at Station 1 and St. 9 with ranged from $2.00 \pm 0.01 \mathrm{mg} \mathrm{L}^{-1}$ to $117.3 \pm 4.16 \mathrm{mg} \mathrm{L}^{-1}$. Turbidity ranged from 3.07 NTU to 93.70 NTU and the highest turbidity was recorded in March 2016 at St. 2.

One-way ANOVA shows no significant difference among stations for nitrite $(\mathrm{P}=0.342)$, nitrate $(\mathrm{p}=0.073)$, ammonium $(\mathrm{p}=0.077)$ and phosphate $(\mathrm{p}=0.24)$, meanwhile silicate $(\mathrm{P}=0.008)$ shows significant difference. Nitrate concentration ranged from $0.00 \mathrm{mg} \mathrm{L}^{-1}$ to $0.18 \mathrm{mg} \mathrm{L}^{-1}$ with the highest concentration recorded in September 2016 at St. 9. The concentration of nitrate was low from March to August 2016 and exceeded the acceptable values of MWQS $\left(<0.06 \mathrm{mg} \mathrm{L}^{-1}\right)$ during rainy seasons from September 2016 to December 2016. While, the concentration of nitrite is low throughout the study period with a range from $0.0 \mathrm{mg} \mathrm{L}^{-1}$ to $0.08 \mathrm{mg} \mathrm{L}^{-1}$ at all sampling stations. Mean ammonium concentration ranged from $0.003 \pm 0.006$ $\mathrm{mg} \mathrm{L}^{-1}$ to $0.64 \pm 0.03 \mathrm{mg} \mathrm{L}^{-1}$. The highest values of ammonium $\left(0.64 \mathrm{mg} \mathrm{L}^{-1}\right)$ were found at St. 9 in September 2016 (Southwest Monsoon). Ammonium level at most sampling stations exceeded the acceptable values for aquaculture activity under the MWQS $\left(<0.07 \mathrm{mg} \mathrm{L}^{-1}\right)$ from September 2016 to January 2017 with a mean of $0.096 \pm 0.05 \mathrm{mg} \mathrm{L}^{-1}$ to $0.368 \pm 0.09$ $\mathrm{mg} \mathrm{L}^{-1}$. Ammonium enters the waterway from several sources including sewage discharge, industrial wastes, runoff from agriculture and aquaculture activities (Anderson et al., 2002; Davies \& Ugwumba, 2013). High ammonium concentration at sampling stations near the fish cage culture area can be caused by the waste effluent from fish cages. Fish cages release nutrients and organic wastes from uneaten fish feed and faeces (Degefu et al., 2011; Kibria et al., 1997). Phosphate concentrations in all sampling stations were mostly higher than the acceptable values for aquaculture activity under the MWQS $\left(<0.075 \mathrm{mg} \mathrm{L}^{-1}\right)$ during the sampling period. The levels of phosphate ranged from $0.02 \mathrm{mg} \mathrm{L}^{-1}$ to 0.86 $\mathrm{mg} \mathrm{L}^{-1}$. The maximum value recorded was in early June 2016 in St. 8 at $0.86 \mathrm{mg} \mathrm{L}^{-1}$. Meanwhile, toward the end of the sampling period in September 2016, phosphate concentration remained constant but still exceeded the acceptable values. Level of phosphate was also high in the aquaculture area of Pulau Aman, Penang throughout the sampling time in year 2011 and January to 
May 2012 with the maximum value of $6.30 \mathrm{mg} \mathrm{L}^{-1}$ (Roziawati et al., 2015). Concentration of silicate ranged from 0.06 $\mathrm{mg} \mathrm{L}^{-1}$ to $6.02 \mathrm{mg} \mathrm{L}^{-1}$. Similar pattern was observed with the ammonium and nitrate contents which showed an increase during heavy rainfall events.

The enhancement of phytoplankton was observed at most sampling stations in months with higher precipitation (i.e. May 2016, September 2016, November 2016 and January 2017) and higher concentration of phosphate, ammonium, and nitrate. It could be due to the increase of nutrient loading into water systems by terrestrial runoffs during heavy rains that stimulated the growth of phytoplankton. Paul et al. (2008) found that nutrient concentration gives a significant impact on phytoplankton growth in which greater nutrient concentration contributes to higher phytoplankton presence. In this study, the diatoms were the dominant group throughout the sampling period, it seems that diatoms were more sensitive than other phytoplankton groups to the increase in nutrients. HABs often occur after heavy rain and runoffs, followed by a period of high sunlight leading to a nutrient increase in the water-column thus triggering the bloom (Anton, 2008; Smadya, 2003). However, blooms of phytoplankton were not recorded in all sampling stations during the study period probably because nutrient concentrations were not sufficiently high to regulate the excessive growth of harmful phytoplankton species.

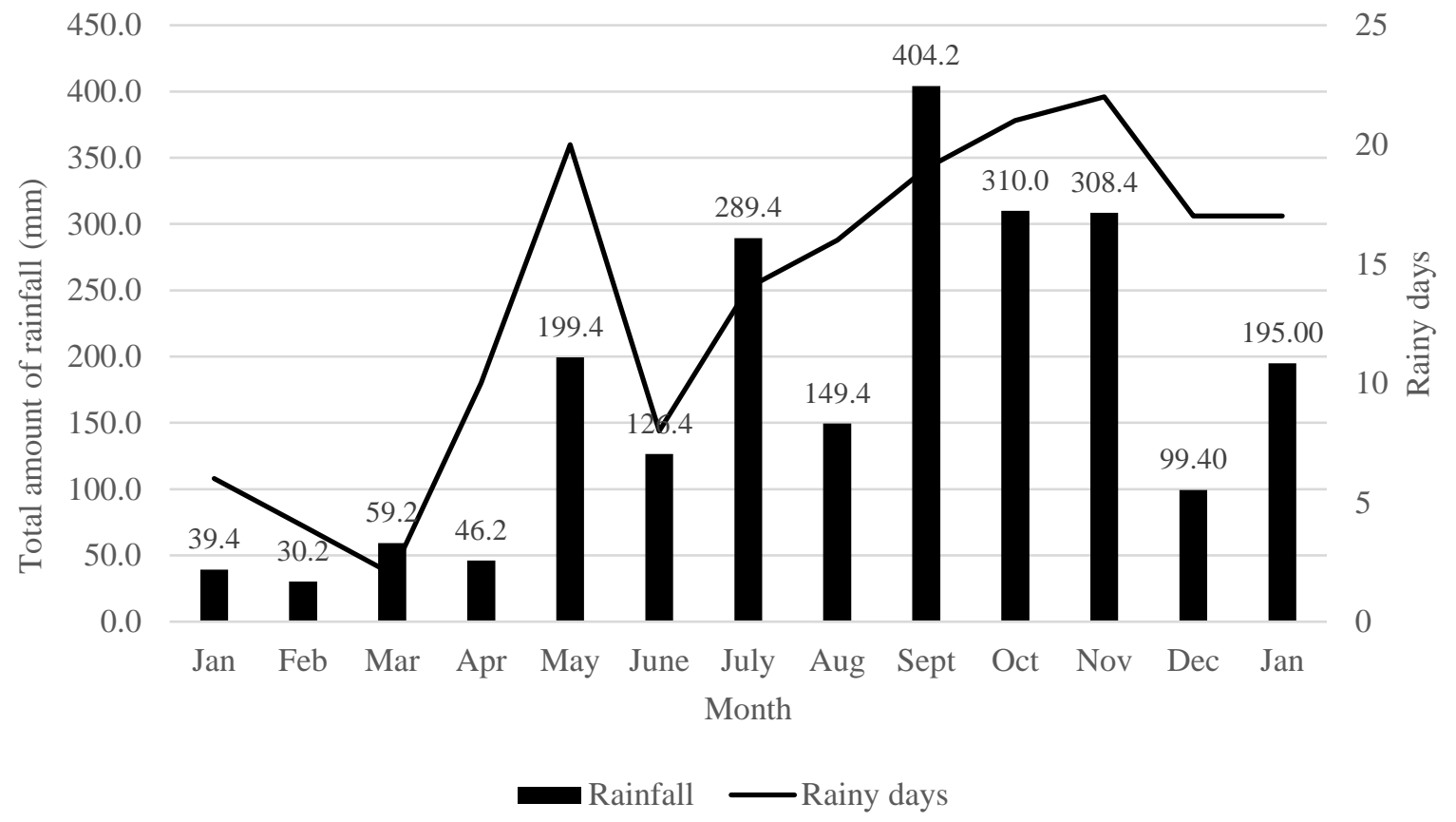

Figure 3. Total monthly rainfall and rainy days in Bayan Lepas, Penang from January 2016 to January 2017 (Source: Department of Meteorological Malaysia). 

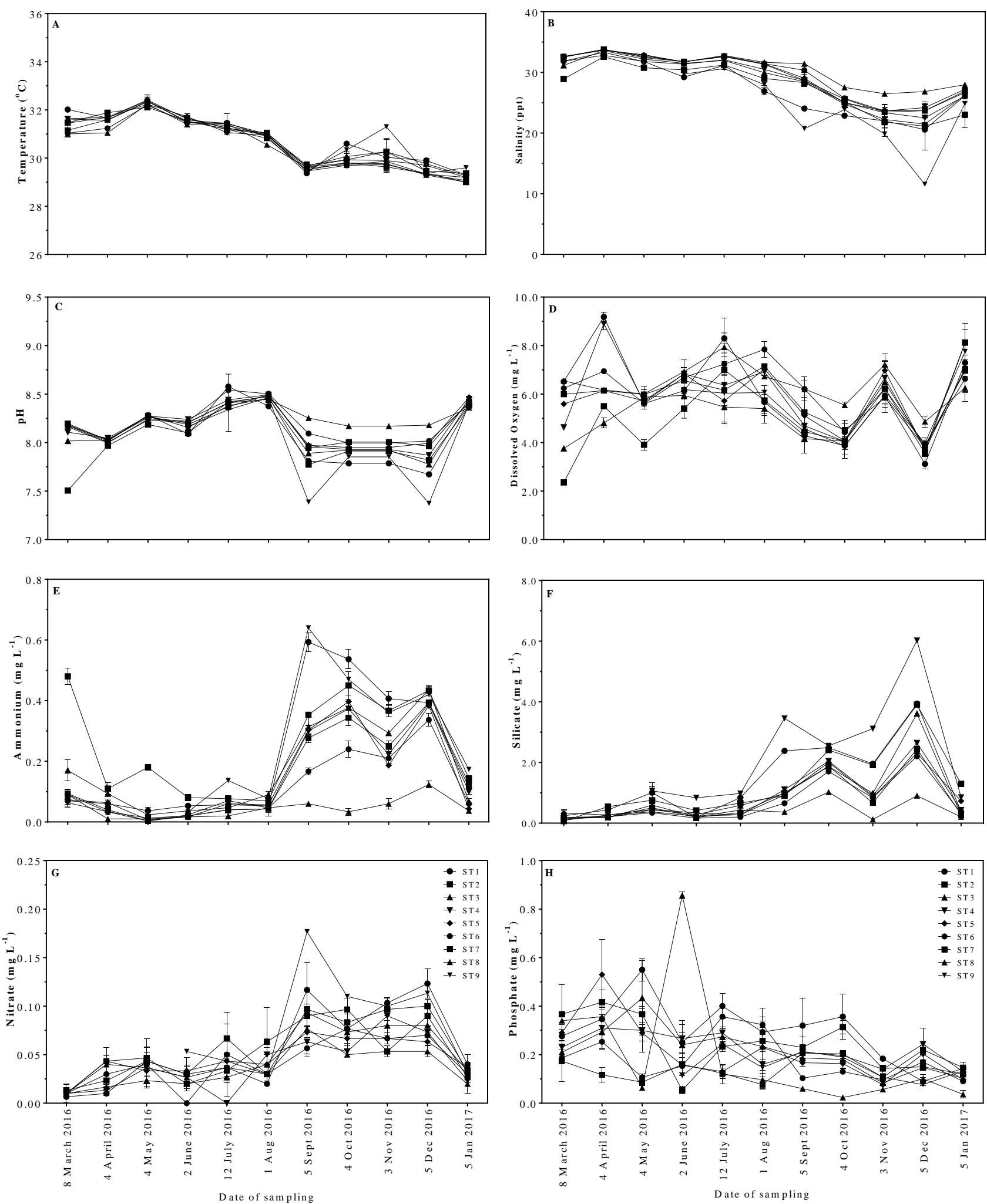

Figure 4. Water parameters of nine stations in Sg. Udang, Penang (A) Temperature, (B) salinity, (C) pH, (D) dissolved oxygen, (E) ammonium, (F) phosphate, $(\mathrm{G})$ nitrate, $(\mathrm{H})$ silicate from March 2016 to December 2017. 


\section{CONCLUSIONS}

Diatoms were the dominant phytoplankton found at all sampling stations throughout the sampling period except in July 2016. In addition, blooms of dinoflagellates were not observed in all sampling stations during the period of study. This study found that most water parameters were within acceptable values for mariculture, based on the Malaysia Marine Water Quality Criteria and Standards during the period of study except for ammonium and phosphate. The presence of potentially harmful phytoplankton species such as Akashiwo sanguinea, Ceratium furca, Ceratium fusus, Karlodinium spp. and Margalefidinium spp. in the fish cages within the area of Sg. Udang waters need regular monitoring even though no case of HABs was reported throughout the study period to safeguard mariculture industries in Sungai Udang, Penang. Distribution data of phytoplankton could be used for risk assessment of potential HABs incidences for early warning and HABs monitoring purposes.

\section{ACKNOWLEDGMENTS}

The authors would like to thank the Senior Director of Fisheries Research Institute, Dr. Zainoddin bin $\mathrm{Hj}$. Jamari for his kind support. Thanks to all support staff in the Impact Assessment Research Division, FRIBM who had helped in sample collection and analysis. This study was funded under the 11th Malaysia Plan, Department of Fisheries Malaysia grant number 22501-041.

\section{CONFLICT OF INTEREST}

We declare no competing interests.

\section{REFERENCES}

AlGheilani, H. M., Matsuoka, K., YahyaAlKindi, A.A., Amer, S., \& Waring, C. (2011). Fish Kill Incidents and Harmful Algal Blooms in Omani Waters. Agricultural and Marine Sciences, 16: 23-33.

Anderson, D.M., Glibert, P.M. \& Burkholder, J.M. (2002). Harmful Algal Blooms and Eutrophication Nutrient Sources, Composition, and Consequences. Estuaries, 25(4b): 704-726.

Anderson, D. (2012). HABs in a changing world: a perspective on harmful algal blooms, their impacts, and research and management in a dynamic era of climatic and environmental change. Harmful Algae 2012: 3-17.

Annual Fisheries Statistics (2017). Vol.1. Department of Fisheries, Ministry of Agriculture. Kuala Lumpur, Malaysia.

Anton, A., Teoh, P.L., Mohd Salleh, S.R. \& Mohd Noor, N. (2008). First occurrence of Cochlodinium blooms in Sabah, Malaysia. Harmful Algae, 7: 331-336.

Antonietta, S.Q. (2016). Automated Detection of Harmful (and/or toxic) Algae 
Blooms (HABs) in Galveston Bay. Final report. Coastal Management Program Texas General Land Office, pp. 1-29, Texas A\&M University, Galveston Campus.

Backer, L.C., Fleming, L.E., Rowan, A.D. \& Baden, D.G. (2003). Epidemiology, public health and human disease associated with harmful marine algae. In: Hallegraeff, G.M., Anderson, D.M. \& Cambella, A.D. (eds.). Manual on Marine Microalgae. Monographs on oceanic methodology 11, pp. 723-749, UNESCO Publishing, Paris.

Bell, G.R. (1961). Penetration of spines from a marine diatom into the gill tissue of ling cod Ophiodon elongatus. Nature, 192: 279-280.

Cardwell, R.D., Olsen, S., Carr, M.I. \& Sanborn, E.W. (1979). Causes of oyster mortality in South Puget Sound. National Oceanic And Atmospheric (NOAA) technical memorandum, ERL MESA-39. Marine Ecosystems Analysis Program Boulder, Corolado.

Carter, C.M., Ross, A.H., Schielb, D.R., Howard-William, C. \& Haydena, B. (2005). In situ microcosm experiments on the influence of nitrate and light on phytoplankton community composition. Journal of Experimental Marine Biology and Ecology, 326: 1-13.

Choo, P.S. (1994). A review on Red Tide occurrences in Malaysia. Risalah Perikanan Bil 60, pp. 1-9, Department of Fisheries Malaysia.

Davies, O.A. \& Ugwumba, O.A. (2013). Tidal Influence on Nutrients Status and Phytoplankton Population of Okpoka Creek, Upper Bonny
Estuary, Nigeria. Journal of Marine Biology: 1-16.

Degefu, F., Mengistu, S. \& Schagerl, M. (2011). Influence of fish cage farming on water quality and plankton in fish ponds: A case study in the Rift Valley and North Shoa reservoirs, Ethiopia. Aquaculture, 316: 129-135.

Department of Fisheries (2007). Study on red tide occurrences in the Coastal Waters off the Northern States of Peninsular Malaysia. Annual Report, pp. 19, Fisheries Research Institute publishing, Penang.

Helleren, S. (2016). The diatom Chaetoceros spp. as a potential contributing factor to fish mortality events in Cockburn Sound, November 2015. Dalcon Environmental Report, pp. 1-29.

Heisler, J., Glibert, P.M., Burkholder, J.M., Anderson, D.M., Cochlan, W., Dennison, W.C., Dortch, Q., Gobler, C.J., Heil, C.A., Humphries, E., Lewitus, A., Magnien, R., Marshall, H.G., Sellner, K., Stockwell, D.A., Stoecker, D.K. \& Suddleson, M. (2008). Eutrophication and harmful algal blooms: A scientific consensus. Harmful Algae, 8: 3-13.

Hallegraeff, G.M. (2003). Harmful algal blooms: a global overview. In: Hallegraeff, G.M. Anderson, D. M. \& Cembella, A. D. (eds.), Manual on Harmful Marine Microalgae. Monographs on Oceanic Methodology 11, pp. 2545, UNESCO Publishing, Paris.

Horner, R.A., Garrison, D.L. \& Plumbley, G.F. (1997). Harmful algal blooms and red tide problems on the U.S. west coast. Limnology and Oceanography: 1076-1088. 
Kibria, G., Nugegoda, D., Fairclough, R. \& Lam, P. (1997). The nutrient content and the release of nutrients from fish food and faeces. Hydrobiological, 357: 165-171.

Kopuz, U., Feyzioglu, A.M. \& Valente, A. (2014). An Unusual Red-Tide Event of Noctiluca scintillans (Macartney) in the Southeastern Black Sea. Turkish Journal of Fisheries and Aquatic Sciences, 14: 261-268.

Lim, P.T., Usup, G. \& Leaw, C.P. (2012). Harmful Algal Blooms in Malaysian waters. Sains Malaysiana, 41(12): 1509-1515.

Lim, H.C., Leaw, C.P., Tan, T.H., Kon, N.F., Yek, L.H., Hii, K.S., Teng, S.T., Roziawati, M.R., Usup, G., Iwataki, M. \& Lim, P.T. (2014). A bloom of Karlodinium australe (Gymnodiniales, Dinophyceae) associated with mass mortality of cage-cultured fishes in West Johor Strait, Malaysia Harmful Algae, 40: 51-62.

Madihah, J.S., Rashed-Un-Nabi, M. \& Azharul, M.H. (2008). Distribution of phytoplankton community in relation to environmental parameters in cage culture area of Sepanggar Bay, Sabah, Malaysia. Estuarine, Coastal and Shelf Science, 80: 251-260.

Majbritt, F.L., Mette, E.B., Atherine, R., Fatimaj, Y. \& Muhamed, S. (2004). Phytoplankton Community Composition and Size Distribution in the Langat River Estuary, Malaysia. Estuaries, 27(4): 716-727.

Normawaty, M.N., Anton, A. \& Mat Amin, N. (2007). Biodiversity of dinoflagellates in the coastal waters off Malacca, Peninsular Malaysia.
The Journal of Science \& Technology, 21: 12-18.

Normawaty, M.N., Siti Nor, R.H., Zainab, M.L., Yukinori, M., Najma, T.M. \& Shahbudin, Y. (2013). Diversity of Phytoplankton in Coastal Water of Kuantan, Pahang, Malaysia. Malaysia Journal of Science, 32(1): 29-37.

NorRohaida, S.H., Normawaty, M.N., Zuhairi, A., Kua, B.C., Shahbudin, S., Nor Salamah, M.H. \& Yukimiri, M.K. (2015). First report of Cochlodinium polykrikoides (Dinophyceae), a harmful algal bloom (HAB) species in the coastal waters of peninsular Malaysia. Malaysian Journal of Science, 34(1): 87-92.

Omura, T., Iwataki, M., Borja, V.M., Takayama, H. \& Fukuyo, Y. (2012). Marine phytoplankton of the Western Pacific. Kouesiha Kouseikaku Co. Lyh., Tokyo.

Pasztaleniec, A. \& Poniewozik, M. (2010). Phytoplankton based assessment of the ecological status of four shallow lakes (Eastern Poland) according to Water Framework Directive - a comparison of approaches. Limnological, 40: 251-259.

Paul, J.T., Ramaiah, N. \& Sardessai, S. (2008). Nutrient regimes and their effect on distribution of phytoplankton in Bay of Bengal. Marine Environmental Research, 66(3): 337-344.

Polat, S. (2007). Effects of nutrient enrichment on coastal phytoplankton composition and abundance in the Northeastern Mediterranean. Pakistan Journal Botany, 39(6): 2087-2095. 
Rensel, J.E. \& Whyte, J.N.C. (2003). Finfish mariculture and harmful algal blooms. In: Hallegraeff G.M. Anderson D.M. and Cembella A.D. (eds.), Manual on Harmful Marine Microalgae. Monographs on oceanic methodology 11, pp. 693-722, UNESCO Publishing, Paris.

Roziawati, M.R. \& Faazaz, A.L. (2011). Potentially harmful microalgae from cockle culture area in $\mathrm{Sg}$. Jarum Mas, Perak. Malaysian Fisheries Journal, 10(1): 91-103.

Roziawati, M.R., Leaw, C.P., Lim, H.C., Nyanti, L., Ismail, I. \& Lim, P.T. (2015). Harmful microalgae assemblage in the aquaculture area of Aman Island, Northern Strait of Malacca. Malaysian Journal of Science, 34(1): 24-36.

Roziawati, M.R., Abu Yazidyusnisab, M., Mohd Fauzi, A., Nurhidayati, A.S., Kamarulzaman, I. \& Mazhidayah, M.R. (2016). Ledakan Noctiluca scintillans di kawasan sangkar ikan marin di Kuala Gula, Perak. The Proceedings of the Fisheries Research Seminar 2016, 25-27 October, pp. 207-210. Fisheries Research Institute Batu Maung, Penang.

Roziawati, M.R. \& Shahunthala, D. (2017). Buku Kompilasi Laporan Kes Kematian Ikan Secara Besar-Besaran 2012-2017. Fisheries Research Institute, Department of Fisheries Malaysia.

Sadally, S., Nazurally, N., Taleb-Hossenkhan, N. \& Bhagooli, R. (2014). Microphytoplankton distribution and biomass in and around a channelbased fish farm: implications for sustainable aquaculture. Acta Oceanologica Sinica, 33(12): 180191.

Schluter, L. (1998). The influence of nutrient addition on growth rates of phytoplankton groups, and microzooplankton grazing rates in a mesocosm experiment. Journal of Experimental Marine Biology and Ecology, 228: 53-71.

Smayda, T.J. (2003). Environmental monitoring, with examples from Narragansett Bay. In: Hallegraeff, G.M. Anderson, D.M. \& Cembella, A.D. (eds.), Manual on Harmful Marine Microalgae. Monographs on oceanic methodology 11, pp. 25-45, UNESCO Publishing, Paris.

Sidik, M.J., Rashed-Un-Nabi, M. \& Hoque, M.A. (2008). Distribution of phytoplankton community in relation to environmental parameters in cage culture area of Sepanggar Bay, Sabah, Malaysia. Estuarine Coastal Shelf Science, 80: 251-260.

Teng, S.T., Leaw, C.P., Lau, W.L., Law, I.K. \& Lim, P.T. (2016). Recurrence of the harmful dinoflagellate Karlodinium australe along the Johor Strait. Harmful Algae News, 52: 5.

Tomas, C.R. (1997). Identifying marine phytoplankton, pp. 858, Academic Press, San Diego.

Veronica, E., Setyo Leksono, A., Soemarno, A. \& Diana, F. (2014). Effect of Water Quality on Phytoplankton Abundance in Hampalam River and Fish Pond of Batanjung Village.Journal of Environmental Science, Toxicology and Food Technology, 8(1): 2319-2399. 
Wan Maznah, W.O. (2010). Perspectives on the Use of Algae as Biological Indicators for Monitoring and Protecting Aquatic Environments, with Special Reference to Malaysian Freshwater Ecosystems. Tropical Life Sciences Research, 21(2): $51-67$.

Willen, E. (2007). Phytoplankton in Water Quality Assessment-An Indicator Concept. In: Heinonen, P., Ziglio, G. \& Van Der Beken, A. (eds.), Water Quality Measurements Series. Hydrological and Limnological Aspects of Lake Monitoring pp. 5680, John Wiley \& Sons, Ltd.

Wurtsbaugh, W.A., Paerl, H.W., \& Dodds, W.K. (2019). Nutrients, eutrophication and harmful algal blooms along the freshwater to marine continuum. WIREs Water, 6(5): 1-27.
Yasser, A.K.A. (2003). Use phytoplankton abundance and species diversity for monitoring coastal water quality. Master thesis. Universiti Sains Malaysia.

Yin, K., Harrison, P.J. \& Black, E. (2008). Risk analysis of coastal aquaculture: Potential effects on algal blooms. Assessment and communication of environmental risks in coastal aquaculture. Rome, FAO. Reports and Studies GESAMP, 76: 176197.

Ying L.K. \& Abdul Naser A.G. (2019). Rainfall Characteristics and Its Effect on Road Infrastructure Health. International Journal of Integrated Engineering, 11(9): 234246. 

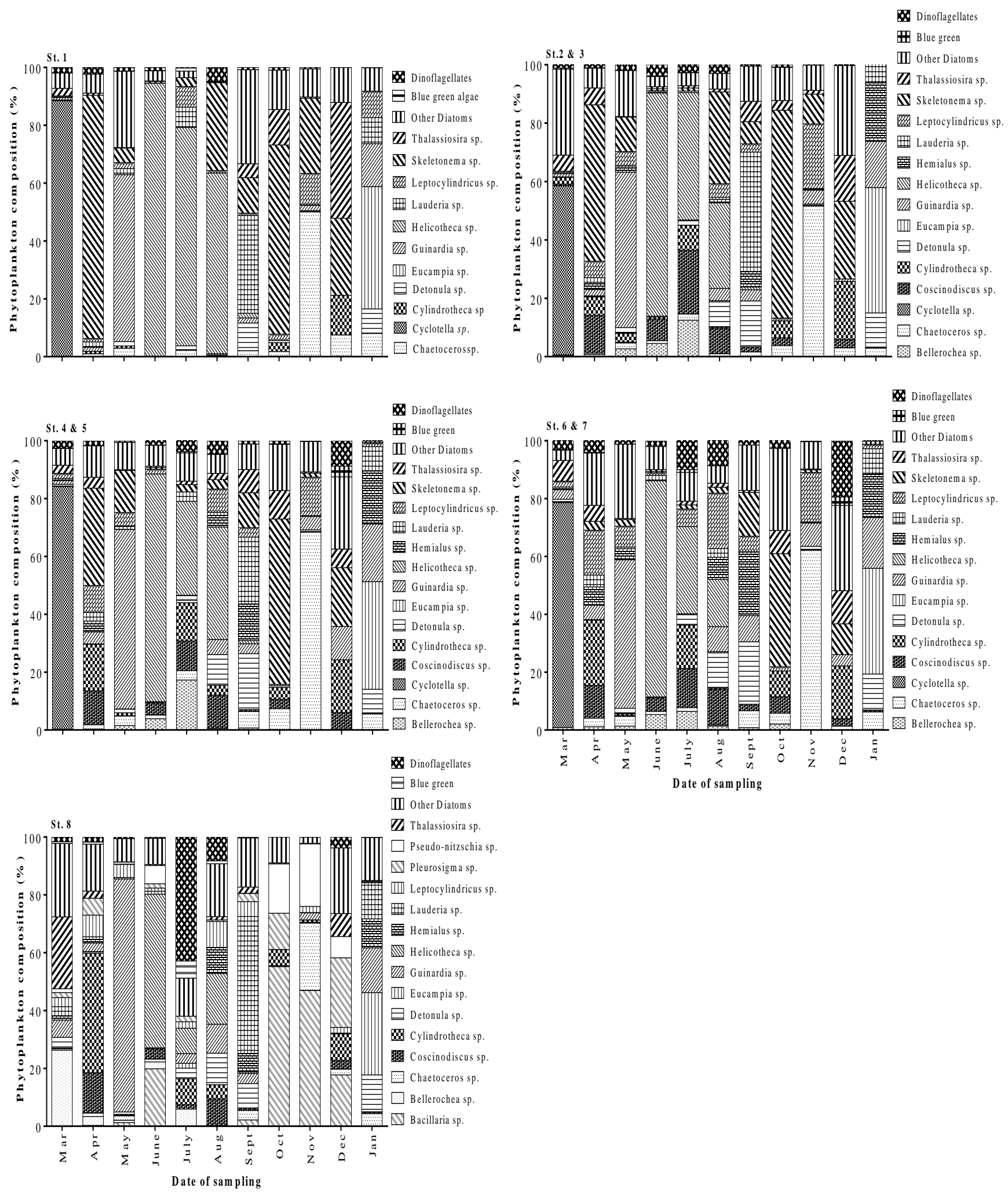

Supplementary Figure: Phytoplankton species composition of Sungai Udang, Penang from March 2016 to January 2017 
Supplementary Table: Mean, standard deviation and range of the physico-chemical parameters at nine sampling stations in Sungai Udang, Penang.

\begin{tabular}{|c|c|c|c|c|c|c|c|c|c|}
\hline Stations & St. 1 & St. 2 & St. 3 & St. 4 & St. 5 & St. 6 & St. 7 & St. 8 & St. 9 \\
\hline Temp. $\left({ }^{\circ} \mathrm{C}\right)$ & $\begin{array}{l}30.83 \pm 0.32 \\
29.30- \\
32.39\end{array}$ & $\begin{array}{l}30.72 \pm 0.30 \\
29.37-32.11\end{array}$ & $\begin{array}{l}30.78 \pm 0.31 \\
29.27-32.41\end{array}$ & $\begin{array}{l}30.71 \pm 0.32 \\
29.20-32.34\end{array}$ & $\begin{array}{l}30.62 \pm 0.33 \\
29.20-32.24\end{array}$ & $\begin{array}{l}30.51 \pm 0.32 \\
29.07-32.20\end{array}$ & $\begin{array}{l}30.54 \pm 0.34 \\
29.00-32.35\end{array}$ & $\begin{array}{l}30.47 \pm 0.31 \\
29.00-32.24\end{array}$ & $\begin{array}{l}30.51 \pm 0.33 \\
29.37-31.59\end{array}$ \\
\hline $\begin{array}{l}\text { Salinity } \\
\text { (ppt) }\end{array}$ & $\begin{array}{l}27.22 \pm 1.33 \\
20.59- \\
32.83\end{array}$ & $\begin{array}{l}27.48 \pm 1.27 \\
21.16-32.58\end{array}$ & $\begin{array}{l}28.51 \pm 1.22 \\
21.48-33.59\end{array}$ & $\begin{array}{l}28.78 \pm 1.17 \\
22.53-33.31\end{array}$ & $\begin{array}{l}29.33 \pm 1.17 \\
23.69-33.77\end{array}$ & $\begin{array}{l}29.65 \pm 1.13 \\
23.65-33.66\end{array}$ & $\begin{array}{l}26.78 \pm 1.16 \\
23.45-33.81\end{array}$ & $\begin{array}{l}30.52 \pm 0.82 \\
26.48-33.66\end{array}$ & $\begin{array}{l}23.64 \pm 2.23 \\
11.42-30.63\end{array}$ \\
\hline pH & $\begin{array}{l}8.09 \pm 0.09 \\
7.67-8.58\end{array}$ & $\begin{array}{l}8.04 \pm 0.09 \\
7.51-8.47\end{array}$ & $\begin{array}{l}8.11 \pm 0.07 \\
7.78-8.46\end{array}$ & $\begin{array}{l}8.15 \pm 0.07 \\
7.87-8.49\end{array}$ & $\begin{array}{l}8.17 \pm 0.06 \\
7.95-8.48\end{array}$ & $\begin{array}{l}8.19 \pm 0.06 \\
7.80-8.54\end{array}$ & $\begin{array}{l}8.17 \pm 0.06 \\
7.95-8.50\end{array}$ & $\begin{array}{l}8.24 \pm 0.04 \\
8.00-8.45\end{array}$ & $\begin{array}{l}7.98 \pm 0.15 \\
7.37-8.46\end{array}$ \\
\hline $\begin{array}{l}\text { DO } \\
\left(\mathrm{mgL}^{-1}\right)\end{array}$ & $\begin{array}{l}5.99 \pm 0.55 \\
3.12-7.29\end{array}$ & $\begin{array}{l}5.12 \pm 0.50 \\
2.36-8.12\end{array}$ & $\begin{array}{l}5.16 \pm 0.33 \\
3.76-6.97\end{array}$ & $\begin{array}{l}6.05 \pm 0.33 \\
3.76-5.95\end{array}$ & $\begin{array}{l}5.81 \pm 0.35 \\
3.69-7.05\end{array}$ & $\begin{array}{l}6.18 \pm 0.35 \\
3.91-7.84\end{array}$ & $\begin{array}{l}5.86 \pm 0.30 \\
381-7.15\end{array}$ & $\begin{array}{l}6.40 \pm 0.25 \\
4.87-7.94\end{array}$ & $\begin{array}{l}5.55 \pm 0.47 \\
3.86-7.75\end{array}$ \\
\hline $\begin{array}{l}\text { Nitrate } \\
\left(\mathrm{mgL}^{-1}\right)\end{array}$ & $\begin{array}{l}0.06 \pm 0.01 \\
0.07-0.12\end{array}$ & $\begin{array}{l}0.06 \pm 0.01 \\
0.01-0.10\end{array}$ & $\begin{array}{l}0.05 \pm 0.01 \\
0.01-0.09\end{array}$ & $\begin{array}{l}0.04 \pm 0.01 \\
0.00-0.09\end{array}$ & $\begin{array}{l}0.05 \pm 0.0 .01 \\
0.01-0.07\end{array}$ & $\begin{array}{l}0.04 \pm 0.01 \\
0.00-0.08\end{array}$ & $\begin{array}{l}0.05 \pm 0.01 \\
0.01-0.10\end{array}$ & $\begin{array}{l}0.04 \pm 0.01 \\
0.01-0.08\end{array}$ & $\begin{array}{l}0.08 \pm 0.02 \\
0.03-0.18\end{array}$ \\
\hline $\begin{array}{l}\text { Phosphate } \\
\left(\mathrm{mgL}^{-1}\right)\end{array}$ & $\begin{array}{l}0.29 \pm 0.04 \\
0.09-0.55\end{array}$ & $\begin{array}{l}0.24 \pm 0.04 \\
0.05-0.42\end{array}$ & $\begin{array}{l}0.22 \pm 0.02 \\
0.08-0.43\end{array}$ & $\begin{array}{l}0.23 \pm 0.02 \\
0.13-0.31\end{array}$ & $\begin{array}{l}0.21 \pm 0.04 \\
0.08-0.53\end{array}$ & $\begin{array}{l}0.18 \pm 0.03 \\
0.09-0.36\end{array}$ & $\begin{array}{l}0.15 \pm 0.01 \\
0.08-0.22\end{array}$ & $\begin{array}{l}0.19 \pm 0.07 \\
0.02-0.86\end{array}$ & $\begin{array}{l}0.15 \pm 0.02 \\
0.08-0.24\end{array}$ \\
\hline $\begin{array}{l}\text { Silicate } \\
\left(\mathrm{mgL}^{-1}\right)\end{array}$ & $\begin{array}{l}1.38 \pm 0.40 \\
0.19-3.93\end{array}$ & $\begin{array}{l}1.29 \pm 0.37 \\
0.07-3.91\end{array}$ & $\begin{array}{l}0.94 \pm 0.34 \\
0.15-3.61\end{array}$ & $\begin{array}{l}0.86 \pm 0.27 \\
0.10-2.64\end{array}$ & $\begin{array}{l}0.83 \pm 0.24 \\
0.23-2.30\end{array}$ & $\begin{array}{l}0.68 \pm 0.23 \\
0.17-2.21\end{array}$ & $\begin{array}{l}0.77 \pm 0.25 \\
0.19-2.21\end{array}$ & $\begin{array}{l}0.42 \pm 0.10 \\
0.12-1.02\end{array}$ & $\begin{array}{l}2.36 \pm 0.65 \\
0.84-6.02\end{array}$ \\
\hline $\begin{array}{l}\text { TSS } \\
\left(\mathrm{mgL}^{-1}\right)\end{array}$ & $\begin{array}{l}31.76 \pm 5.78 \\
11.00-70.33\end{array}$ & $\begin{array}{l}23.97 \pm 4.00 \\
10.00-48.67\end{array}$ & $\begin{array}{l}17.18 \pm 2.47 \\
10.67-37.67\end{array}$ & $\begin{array}{l}17.61 \pm 1.15 \\
12.33-22.00\end{array}$ & $\begin{array}{l}12.00 \pm 1.18 \\
6.33-18.67\end{array}$ & $\begin{array}{l}13.73 \pm 1.48 \\
6.67-22.00\end{array}$ & $\begin{array}{l}13.94 \pm 1.52 \\
6.67-22.00\end{array}$ & $\begin{array}{l}24.85 \pm 5.17 \\
2.00-55.00\end{array}$ & $\begin{array}{l}36.67 \pm 12.55 \\
11.33-117.3\end{array}$ \\
\hline
\end{tabular}

